\title{
Utilising Reflective Practice Groups as pedagogy in ordination training and theological development
}

\author{
Abstract \\ With the Church of England's (2014) recent formation criteria now requiring ordinands to have a greater degree \\ of reflexive capability, this article considers the pedagogy of Reflective Practice Groups in ordination training and \\ focuses on how reflexivity can be developed in a group context, towards fostering greater spiritual formation, \\ theological reflection, self-awareness, relational practices for pastoral encounter, resilience and self-care \\ practices for ministry. Some 'foci for reflexivity' are advocated for use within Reflective Practice Groups in \\ ordination training.
}

\section{Keywords}

Ordinand, training, reflexive, reflective practice, group, clergy 


\section{Introduction}

Ordination training within the Church of England (CofE) has undergone many changes over the past hundred years (Reiss 2013). In recent years, it has become increasingly important for ordinands in the CofE to become reflexive practitioners ${ }^{1}$ (Church of England 2014, 10-15). This is bringing about a shift of focus in pre- and postordination training, from training for a 'professional style of ministry, to training for a more embodied approach to ministerial leadership' (Ladd 2014, 358-359).

Whilst some (e.g. Ixer 1999; 2010) question the speculative and conjectural nature of reflective practice, it enables the development of one's ability to understand the part that one plays in a situation, and what one brings to an encounter with others, enabling the formation of deeper insight and relationality, and a more developed ability to deal with, and survive, complex situations - thus enabling better care, quality of encounter and self-care (Walton 2014). In a ministerial context, reflective practice can enable better preaching (Craddock 2002), self-care (Burton and Burton 2009; Lee and Horsman 2002), pastoral encounters (Kelly 2012; Lyall 2009), missional leadership (Diocese of Glasgow and Galloway 2012) and 'regenerative practice' (Nash 2011).

Reflective Practice Groups ${ }^{2}$ provide a confidential space where participants' practice, the pastoral care of others and the impact of their ministry upon themselves can be explored. They are boundaried, intentional groups in which reflexivity is facilitated. Reflexivity is seemingly promoted as a modern phenomenon (Thompson and Thompson 2008), yet it has long been inherent in a method of theological reflection termed, 'Heart Theology', which 'looks to the self and the interior life as the primary space in which theological awareness is generated' (Graham, Walton and Ward 2005, 18). This form of theological reflection has its roots in the writings of Augustine (Graham, Walton and Ward 2007, 51), and was developed further by the Pietist Movement. Friedrich Schleiermacher (1768-1834) - the father of Practical Theology - was theologically influenced by 'Heart Theology'. In developing his theological paradigm, Schleiermacher highlighted the importance of psychological understanding (i.e. what he called Divination - or intuitive perception), alongside the historical study of scriptural

1 Walton $(2014, \mathrm{xvi})$ states that the types of questions that reflexive enquirers ask of themselves include: 'How does my personal history generate presuppositions that influence my approach to this topic? How does my gender/ class/ ethnicity/ sexual identity/ cultural location influence my understanding? Where do my allegiances lie, and how do my commitments guide my approach to inquiry? What can my body and my emotional responses contribute to generating the knowledge I seek?'

${ }^{2}$ A Reflective Practice Group is defined as 'a non-directive, closed group that aims to offer opportunities for reflection on interactions and processes in which reflexivity can take place at a psychological, relational, spiritual and theological level' (Gubi, 2011, p. 50). 
text (or dogmatics), in the process of hermeneutics, which is 'deeply self-involving' and derives from 'the passionate human engagement with theology' (Crouter 2005, 124).

The pedagogy utilised to develop interior theological reflection has historically been autobiographical accounts, letters, journaling, verbatim reports and creative writing (Walton 2014). Yet, Reflective Practice Groupwork is also an important pedagogy. Some (e.g. Rhymes 1993, 188-193) have argued for the training of ordinands to embrace the formation of small groups, as a form of pedagogy, in which the deepest expressions of humanity can be made and received, 'to experience at those times a sense of what might be called 'the beyond in our midst', 'a depth of life', 'a sense of God"' (194). Citing Moltmann (1973, 86), Rhymes (1993) states that, 'being there for others has as its end to be with others in liberty; being there for others is the way to redemption of life; being there for others is the form which the liberated and redeemed life has taken' (195). Bonhoeffer (1954/2015) also placed great emphasis on Christian community (of which a Reflective Practice Group is one form) and on the importance of each individual in the community (group); on the importance of sharing 'gifts of faith' with others in the community; of discovering about self, others and God; of being with yourself and knowing yourself; and of bearing each other's burdens; and the appropriate place of meekness (e.g. learning sometimes to stay appropriately silent) in community. In developing the concept of 'Lifelong Learning' in ministerial training, Ward (2005) primarily promotes the pedagogy of 'pastoral supervision' as 'the place to play and inter-play' theologically. However, much of what Ward argues as being beneficial from that process of pastoral supervision is also applicable to the use of Reflective Practice Groups in theological education. Drawing on the work of Taylor (1972), Ward (2005) emphasises the need for a space in which 'God is there on the inside of human relating, undergirding the ways in which relatedness between self and other is carried forward without collapsing otherness into the self' (95). This enables differences to be valued, and an opportunity for the Holy Spirit to 'dance around (perichoresis)' (97). Ward elaborates on the importance of developing the capacity to listen, to contract, to maintain and develop appropriate boundaries - all of which can be developed in Reflective Practice Groups. In that safe environment, there is the opportunity to experiment, to 'play' theologically, and to practice alternative scenarios with others.

Others (e.g. Sims, 2011) have promoted the need for developing a 'capacity for reflection' in responding theologically to 'the complexity of ministry in an increasingly pluralistic world' (166). Sims, drawing on the works 
of Schön (1984), Wolfe and Kolb (1980), places great importance on the 'tacit knowing' that, in the context of Ministry, contributes to a repertoire of pastoral responses that spring from the unconscious, and enables a knowing-in-action. This knowing-in-action, then leads to a reflection-in-action, then a reflection-on-action and then to a reflection-for-action. This, according to Schön (1984), is the process for the reflexive practitioner. Engaging in this process keeps vitality alive in ministry and prevents past mistakes from occurring (Sims, 2011, 169). Drawing on Wolfe and Kolb's (1980) Learning Cycle, but adding a theological perspective, Sims (2011) has developed the following further definition to the Four Stages of Adult Learning (see Figure 1 - non-italicised columns). Sims (2011, 172-173) states that adding the theological perspective to the Four Stages of Adult Learning enables a theologically reflexive ministry, in that:

- in sensing the presence and action of God, the clergyperson discerns where God is present and where God is acting. This requires humility and attentiveness;

- in discerning God's purpose, the clergyperson is required to stand back from the situation and reflect on what may be God's desires for the person(s) with whom they are ministering, as well as God's hopes for the way that they are ministering;

- in integrating into one's theology, questions of consistency with current practice of ministry or faith, are asked. Holding the tensions within personal theology may be required;

- and in deciding to co-operate with God, the clergyperson's personal theology may be revised which leads to new implications for pastoral and ministerial practice.

All of these aspects inform the person's current and future practice. If such reflexive practice is engaged with, then learning can be 'deep', and different from much of the 'surface learning' that goes on in ordination training. 'Quality' ministry is more likely when theologically reflective practice is engaged in using Sims' proposed theological lens of 'sensing the presence and action of God, discerning God's purpose, integrating into one's theology, and deciding to co-operate with God' (175). Sims' (2011) notion of theological reflective practice has much to commend it, but to make it 'theologically reflexive practice', Gubi (2016a) has suggested another column focussed on reflexivity: 'What am I noticing about myself in relation to other, and how might I 'be' different? (see Figure 1 - italicised column). This further level of awareness, required of reflexivity, enables a deepening of the awareness of the part (and the past) that the person brings to the encounter, or to the experience, that the 
person is faced with. This, in addition to the other areas of attention identified by Sims (2011), arguably provides a more reflexive response, which enhances self-awareness and deepens insight, enabling a better pastoral and theological response, in keeping with the development of reflexive theology and reflexive practice.

\section{INSERT FIGURE 1.}

Kelly (2013) argues for a movement away from habitus (i.e. the acquisition of knowledge) to phronesis (i.e. practical wisdom which involves developing sound judgment and wisdom formed from reflection on previous experience to inform practice in the present). Kelly (2013) argues for group theological reflective practice, in which someone presents a verbatim (i.e. an experience that they have encountered). The facilitator encourages the other group participants to respond to what has been presented in a way that is non-judgmental and tentative, using three types of response that reflect types of Greek words used in the discovery of the empty tomb in John 20: 1-9 - notice (blepo), wonder [or theorise (theoro)], and realise (horao). In preparation, the presenter of the verbatim engages with the following questions (summarised from Kelly 2013, 249):

- 'What was this experience about - for other(s) and for me?

- Whose need was being met - and how?

- What were its implications for other(s) and for me?

- What does it tell me about my pastoral ability?

- What questions does it raise about God, my values, beliefs, worldview/ frame of reference?'

These questions are designed to promote phronesis in the participant's practice. During the session, the verbatim presenter shares his responses to the questions, and the other group participants are invited to respond in a manner that promotes reflection. In evaluating groups that practiced this form of theological reflection every four to six weeks for over a year ( $n=70$ Chaplains), Kelly $(2013,250-252)$ found that $95 \%$ felt that the experience had impacted positively on their spiritual care practice (identified as: it encouraged a habit of continual reflection on practice, it encouraged a habit of continual reflection on developing self-awareness, it alerted participants to their own developing spiritual needs, it enhanced their spiritual lives, it enabled them to filter content of what to 
share with patients); $85 \%$ felt that the experience of reflecting theologically together had positive effects on their relationships within their teams; $83 \%$ felt that the groups enhanced their resilience and vocational fulfilment (identified as a renewed sense of meaning and purpose in their spiritual care practice, and as a means of staying well in a demanding and draining role). These are impressive results. Kelly concludes his research article by translating what has been developed as group theological reflective practice, into what he terms 'Values Based Reflective Practice', in an attempt to promote its use as embedded practice within a secular healthcare service. In so doing, Kelly arguably gives more attention to the reflexive elements of the focus by examining 'values', in that he promotes the questions (summarised from Kelly 2013, 254-255):

- Whose need(s) were met during the encounter?

- What does this experience tell me about my caring ability?

- What does it tell me about me?

- What questions does it raise about my values (that inform my attitudes and behaviours)? i.e. With whom did the power lie? Whose voice(s) dominated or have most value: Whose voice(s) were not heard or undervalued?

- What future action will you take in relation to this encounter? i.e. For the wellbeing of the patient/career/member of staff or others involved? For your own future practice? For your own wellbeing?

These important questions are arguably less promoted in his group theological reflective practice, but belong there, along with the theological, in developing greater reflexivity among participants.

Writing as a person who is responsible for Ministry and Formation at a CofE Theological Education Institution (TEI), Ladd (2014) argues for a more 'embodied approach' to ministerial development, in which the minister is enabled 'to work hard to attend, and help people to attend, to the subjectivity of the other' (359). This can lead to the valuing of the contribution of each person in the life of the Church, which Ladd (2014) argues reflects Paul's desire for a Christian Community (1 Corinthians 11:17- 14:40) that honours minority voices and promotes the discipline of community discernment. In arguing for this, Ladd unwittingly seems to express the experience of what can occur in Reflective Practice Groups: 
'There is a mystery to the other that is not to be violated or controlled but protected on a journey in which identity and mutual knowing is formed through relationship. This journey of inter-subjectivity involves an attentive effort that [can be] described as the movement from 'sensation' to 'perception'. 'Sensation' sees the other as an object. 'Perception' is a deliberate choice to listen and not just to look. It is a journey in which we refuse to allow the relationship to be reduced to a single subjectivity, refuse to appropriate the other, but allow her to be 'other' in embodied relationship. Furthermore, this journey of openness to the subjectivity of the other is one in which we must be prepared to guard that subjectivity in ourselves and in the other. The goal is not fusion, but rather a relationship between two subjects, the intention of which is to leave to the other his or her subjectivity. [This allows rooms for] a silence [or 'third space'] in which there is room for genuine attention to difference, to the history of each, not least to the party whose history has most consistently been unheard... This practice involves the developing of boundaried listening; the creating of a third space in community - a truly hospitable space - where people learn to attend to each other's personhood. This challenges the temptation to fusion, the melting away of human boundaries in a quest for 'the answer' or 'our way of doing things' that preoccupies the life of so many communities, consciously or subconsciously' (Ladd 2014, 359).

Theological reflection needs to be learned in context and in relationship (community), as spiritual discernment. Greater emphasis in theological education should be placed on learning in placement, supervised by 'educational practitioners' who are engaged in self-aware theological reflection on ministry. However, Ladd's arguments are a strong justification for the development of Reflective Practice Groups in TEls, as a way of 'building reflective 'hubs' of (6-8) students... that enable theological reflection in context to be the heart of ministerial training with genuine attention to what it takes to form community that attends to people's subjectivity, and which is at home in building relationship with the stranger... and encourages reflective learning and development as a norm for ministers and congregations alike' (363).

\section{Using Reflective Practice Groups in ordination training}


Whilst group work does exist in ordination training, these groups, as identified in Gubi (2016a), often do not sufficiently fulfil the definition of a Reflective Practice Group as they are either too structured, contain a formal educative agenda, meet too infrequently or don't seem to give participants much time to explore anything at depth. All of these groups appear to be tutor-led, or tutor-facilitated, which potentially establishes a difficult dynamic within the participants of being able to express honest reflection, whilst knowing that they are being formally assessed (implicitly, if not explicitly), making the spaces potentially 'measured' in terms of what can be shared - 'will they ordain me if I express my doubts of faith?' In counsellor training contexts, personal development groups (a form of Reflective Practice Group) are usually facilitated by external facilitators who have no assessment role, for this reason, thereby enabling a more honest and open reflection (Johns 2012; Rose 2008; Lennie 2007). Whilst Reflective Practice Groups and are not the only method of facilitating self-awareness and reflexivity (Nash and Nash 2009), they enable core assumptions, beliefs, values and attitudes to be made visible to the person because of the group interaction. These colour our interactions and relationships with other people, our perceptions and feelings about the world and the meaning of life (Johns 2012). Within a spiritual formation context, there is a need for a place where an ordinand can feel held and supported, as s/he moves from a more unquestioned acceptance of faith into a deeper mysticism of faith which is characterised by uncertainty, as reflexivity and faith develop. Reflective Practice Groups can provide a space where assumptions, beliefs, values and attitudes can be fully revealed and tested in comparison with others' attitudes, through gaining responses and feedback from other people, and from seeing and feeling how behaviour, which is driven by our values, directly affects and is perceived by other members of our world (McLeod and McLeod 2014; Johns 2012; Rose 2008; 2012). However, they only sometimes lead to positive outcomes (Gubi 2017a; Williams and Irving 1996) and can sometimes be destructive and dysfunctional (Lennie 2000). Benson (1987) observes these 'negatives' as: feeling excluded or scapegoated; suffering the insensitivities, righteous, relevant or inappropriate anger and clumsiness of others; feeling unsafe and uncontained, over-dependent on or hostile to peers or group leaders; feeling bored, frustrated, impotent or critical of self and /or others - all of which can occur for group participants at any time. Moon $(2004,134)$ states that not all learners find reflexivity easy, and Robson and Robson (2009) argue that the need to feel 'safe' is important, and such groups don't always feel safe. 
Yet, much has been written about the value and process of groups in the psychological literature (e.g. Preston-Shoot 2007; Jaques and Salaman 2006), and they are valued as a means of developing self-awareness (Johns 2012; Mearns 1997). Being in a Reflective Practice Group can:

- '[enable] experience in interactions with other people in very concrete and immediate ways, which can reinforce effective interpersonal patterns, challenge unhelpful ones and allow for possible changes to be tested out;

- reduce loneliness and isolation belonging to age and stage, life space or existential uncertainties by providing a supportive, bonded, at times loving, connection with peers in a shared, purposeful activity;

- provide opportunities to see and feel the consequences of our projections of others;

- offer, in other group members, a range of alternative models of being, behaving and communicating which may assist in us loosening or even changing some of our own constructs and straitjackets in feeling, thinking and acting' (Johns 2012, 157).

They are a vibrant context for identifying personal development needs (Dryden et al. 1995). If an atmosphere of trust and spirit of encounter can be developed in a group, the members can help each other identify needs which might otherwise have been blind-spots. The participants of Reflective Practice Groups share relationships in other spheres which may impact on how an individual communicates within the group, and whether they get to know others in a meaningful way or remain hidden within the group (Lennie 2007). Within the American Catholic Church, Reflective Practice Groups are used in ordination training to cultivate spirituality (Foster et al. 2006) their purpose is 'the creation of a space in a busy calendar to tend to students' spiritual growth, and to centre the spiritual life of the seminary community thus contributing to the students' spiritual development' (281).

\section{Including Reflective Practice Groups in the curriculum}

As the formation criteria for ordinands has moved towards developing a greater ability to be reflexive (The Archbishops' Council of the Church of England 2003; Church of England 2014), and towards lifelong learning in ministerial education (Ward 2005), so the pedagogy within TEls needs to change (and is changing) to accommodate these formation requirements. The literature and the data from Gubi (2016a), suggests that this 
shift in pedagogy, with the use of Reflective Practice Groups, will enable 'deep learning' (Rhymes 1993; Harkness 2012).

In my experience of working in Higher Education Institutions, there is always pressure to cover an extensive curriculum in a finite period of time, which is measured against learning outcomes. One of the main objections to reflexive practice is that reflexivity cannot be measured objectively (Ixer 1999; 2010) - although a person's sense of their own growth and development (psychologically and theologically) can be expressed subjectively, with the inner journey and thinking demonstrated though journaling and written assignments (Bolton 2014). Many TEls run a mixed mode of attendance (full-time and part-time), with some being residential courses and some being non-residential. TEls have had to develop a flexible approach to ordination training to accommodate an increase in those who are intending to serve in non-stipendiary ministry (or localised unpaid ministry) who also work full-time whilst training (Reiss 2013). Therefore, the argument can be convincingly made, that to include a Reflective Practice Groups on a regular basis, is to seemingly have to accommodate another 'something' in an already tight schedule of material to cover. However, these groups can enable a 'letting go' of some of the more formal approaches to learning through 'input' (surface learning), to enable a more informal, but boundaried, space to emerge in which learning can take place from within the group, following the group's agenda for learning (Where is my/your dissonance or joy? What am l/you learning about my/yourself in this experience? Where is God in this? How might I have done that better?), i.e. Ladd's (2014) 'embodied approach'.

\section{The benefits of Reflective Practice Groups in ordination training}

The place of Reflective Practice Groups in supporting clergy is increasingly researched and documented (e.g. Gubi 2016b; Gubi and Korris 2015; Barrett 2010; Travis 2008). Gubi (2016b; 2017a; 2017b) demonstrates that a Reflective Practice Group is a place where the seeds of self-reflection are sown and nurtured, which can continue to be nurtured after training, as a culture of taking part in Reflective Practice Groups would be established. The essential nature of developing self-awareness in building self-sufficiency and resilience, and the role of these groups in assisting that development, is evident in the literature (Gubi and Korris 2015; Barrett 2010; Travis 2008). Reflective Practice Groups can enable a better culture of self-care to be established, alongside the development of a more fluid attitude to ministry and theology (Gubi 2016a; 2016b). Their inclusion in TEls is beneficial in 
enabling ordinands to function with a kind of psychological literacy. They can be a pedagogy that enables ordinands to flourish and feel more supported in their training and ministries. The benefits of Reflective Practice Groups are identified as offering support, enabling clergy to feel less isolated, enabling clergy to gain an insight into the way that they think and into the impact of their way of being on others. They enable clergy to respect difference better and to gain a better sense of self-care. The Reflective Practice Group enables clergy to engage in a better quality of pastoral encounter with others and to interact better with others in their ministry. They are identified as enabling clergy to grow as human beings, enabling trust and vulnerability to be experienced safely. They enable clergy to negotiate boundaries better; feel listened to and valued; assist them in learning to listen to others better and learn from others; to value their own ministry more; have space to think and reflect; gain permission to be one's self; gain the realisation that one is not alone in the struggles of ministry; gain a place to vent frustrations and express difficulties; and a place to reflect theologically and practically (Gubi and Korris, 2015; Barrett 2010; Travis 2008; Gubi 2016a; 2016b; 2017c). So, there is evidence that Reflective Practice Groups are effective in supporting clergy in their ministry, and the culture of seeking support from them can begin in TEls.

\section{Formulating practice}

Charry $(1997,18)$ argues for forms of 'divine pedagogy' in TEls, which are the means by which theology is developed, that informs the processes which enable the formation of character and assists in the building and maintaining the community of faith and enables the communication of that faith to the wider world. There is a divine dimension to the origin of all experience which requires the ability to reformulate one's theology in order to express the truth which the theology intends (Kinast 1996, 122). This involves the use of reflexivity in the formation of ordinands. Developing this level of reflexivity demands time to honestly reflect, and a willingness to be vulnerable to re-enter a dissonant situation and consider the situation critically from a variety of perspectives (Denniston 2014). The reflexive element to this involves a search of self, and of one's own process, to know what one has brought to an experience (or encounter), as well as engaging with the perceptions of tradition, faith positions and biblical understanding, towards a personal and theological reflection, and an appropriate pastoral response. One place to develop this level of reflexivity and phronesis is Reflective Practice Groups. 
As a means of formulating practice, I advocate some 'foci for reflexivity' (see Figure 2). These foci for reflexivity enable a fairly systematic approach for the development of reflexivity within the Reflective Practice Group context and include the psychological and the spiritual/ theological. Recommendations for instigating Reflective Practice Groups are:

- That they are not structured in its content (i.e. it is non-directive, but focussed on psychological and spiritual process, holding the foci for reflection in Figure 2 with attention). The content emerges from what is 'around' for the group participants.

- They should consist of between six and ten participants each who negotiate an agreement (covenant or contract) consisting of confidentiality and practicalities (time, place, frequency, cost).

- They should meet weekly in Theological Colleges/ Seminaries (preferably), and monthly in dioceses or Church communities, for at least one and a half hours (preferably two hours).

- They should be facilitated by an external facilitator (who is preferably counsellor/psychotherapy trained and not on the staff of the same Theological College/ Seminary as the participants, or who is likely to have dual relationships with participants) who is trained in group facilitation and group process, and who is able to facilitate at a spiritual- and psychological- process level.

- The facilitator keeps the group focussed on the internal reflexivity task, and the sharing within the group of that, embodying and exemplifying a quality of servanthood, service and hospitality. The time is not to be divided equally between participants, nor does everyone have to speak. However, a good facilitator will 'notice' and 'invite' non-contributors as appropriate.

- Participants, too, will be encouraged to listen deeply, share appropriately and facilitate each other with the foci for reflexivity in mind.

- Having two facilitators for each group has its own (arguably useful) dynamic, but given the limited financial resources in many communities, having two facilitators is not necessary.

- Facilitators mindfully hold awareness of the aspects that may limit a group and do what they can to overcome them where possible.

- Because there is always the potential for the process to become unhelpful, facilitators will need to be in supervision. 
- Facilitators will also need to be able to facilitate fluidly in ways that move relatively easily between the spiritual (theological) and the psychological.

\section{INSERT FIGURE 2}

\section{Concluding comment}

This article has argued the value of Reflective Practice Groups in ordination training. Utilising them in TEls supports formation, develops phronesis, and enables the spiritual discernment and theological reflection within community. They are a valuable form of support and because 'spiritual dryness' is a primary predictor of emotional exhaustion, they need to nurture an ongoing and renewing relationship with God, to maintain life balance, reduce stress and avoid burnout. 'Seminaries... [i.e. TEIs] can assist their candidates to develop healthy personal practices [and should be] a crucial curricular consideration' (Chandler 2009, 285). Braudaway-Bauman (2012), likewise, argues for a community of practice for intentional reflection. Reflective Practice Groups provide participants with a safe place to 'act from the centre' in order to 'give God freedom in the world, to do the works of God' (Williams 2000). They are also a form of Bonhoeffer's ecclesiology of 'Christ existing as community' as both a form of 'Church' (i.e. Christian community), and as a place that enables and sustains 'Church... to be there for others...', enabling the facilitation and articulation of limitations, struggles and failures (McBride 2014, 92-95). With the emphasis within the 'Formation Criteria for Ordained Ministry' now on the development of reflexivity (Church of England 2014, 10-15), Reflective Practice Groups would be a helpful way of responding to those formation criteria, developing a heart theology, and fostering good self-care practices for future ministry. Indeed, the future of the Church may depend on clergy developing, and having, those skills.

\section{References}

Barrett, Julia. 2010. Living the practice: A research inquiry into clergy use of Reflective Practice Groups in the Exeter Diocese of the Church of England. Unpublished MA dissertation: University of Middlesex, UK.

Benson, Jarlath F. 1987. Working more creatively in Groups. London, UK: Routledge.

Bolton, Gillie. 2014. $4^{\text {th }}$ Edition. Reflective Practice: Writing and Professional Development. London, UK: Sage Publications.

Bonhoeffer, Dietrich. 1954/2015. trans. J.W. Doberstein. Life together. London, UK: SCM Press. 
Braudaway-Bauman, C. 2012. Peer Power: The promise of clergy support groups. Christian Century, 11: 22-25.

Burton, Jean, and Chris Burton. 2009. Public People, Private Lives: Tackling stress in clergy families. London, UK: Continuim.

Chandler, D.J. 2009. Pastoral burnout and the impact of personal spiritual renewal, rest-taking, and support system practices. Journal of Pastoral Psychology, 58: 273-287.

Charry, Ellen T. 1997. By the Renewing of your Minds: The Pastoral Function of Christian Doctrine. Oxford, UK: Oxford University Press.

Church of England. 2014. Formation Criteria with mapped selection criteria for Ordained Ministry in the Church of England. https://www.churchofengland.org/media/2139103/formation criteria for ordained ministry approved hofbps dec 2014.docx

Craddock, Fred B. 2002. Overhearing the Gospel. St. Louis, USA: Chalice.

Crouter, Richard. 2005. Shaping an Academic Discipline: The Brief Outline on the Study of Theology. In The Cambridge Companion to Freidrich Schleiermacher, ed. Jacqueline Marina, 111-128. Cambridge, UK: Cambridge University Press.

Denniston, Jane. 2014. Theory into Practice: A challenge for supervisors in formation for ordained ministry. In Enriching Ministry: Pastoral supervision in practice, ed. Michael Paterson and Jessica Rose, 105-118. London, UK: SCM Press.

Diocese of Glasgow and Galloway. 2012. http://md.glasgow.anglican.org/wp-content/uploads/2011/09/20122013-CMD-Handbook.pdf

Dryden, Windy, lan Horton and Dave Mearns. 1995. Issues in Professional Counselling. London, UK: Cassell.

Foster, Charles R., Lisa Dahill, Larry Goleman and Barbara Wang Tolentino. 2006.. Educating Clergy: Teaching practices and pastoral imagination. San Francisco, CA, USA: Josey-Bass.

Fowler, James W. 1981. Stages of Faith: The Psychology of Human Development and the Quest for Meaning. New York, USA: Harper and Row.

Graham, Elaine, Heather Walton and Frances Ward. 2005. Theological Reflection: Methods. London, UK: SCM Press.

Graham, Elaine, Heather Walton and Frances Ward. 2007. Theological Reflection: Sources. London, UK: SCM Press.

Gubi, Peter Madsen. 2016a. Exploring the value of (Spiritually) Reflexive Practice Groups in the training of ordinands and in supporting ordained persons in ministry. Unpublished ThD Thesis. University of Winchester, UK.

Gubi, Peter Madsen. 2016b. Assessing the perceived value of Reflexive Groups for supporting Clergy in the Church of England. Journal of Mental Health, Religion and Culture. 19, no. 4: 350-361.

Gubi, Peter Madsen. 2017a. Assessing the perceived limitations of Reflexive Groups for supporting Clergy in the Church of England. Journal of Mental Health, Religion and Culture. 19, no. 7: 769-780. 
Gubi, Peter Madsen. 2017b. The use of Reflexive Practice Groups in spiritual development. In What Counsellors and Spiritual Directors Can Learn from Each Other: Ethical Practice, Training and Supervision, ed. Peter Madsen Gubi, 86-102. London, UK: Jessica Kingsley Publishers

Gubi, Peter Madsen. 2017c. Embracing reflexivity through Spiritually Reflexive Practice Groups in the training and support of clergy. The Hinge: International Theological Dialog for the Moravian Church. 22, no. 1: 1-40.

Gubi, Peter Madsen and Jan Korris. 2015. Supporting Church of England Clergy through the provision of Reflective Practice Groups. Thresholds: The Journal of BACP Spirituality Division. Winter: 20-24.

Gubi, Peter Madsen. 2011.

Gunton, Colin, E. 1993. The One, the Three and the Many: God, Creation and the Culture of Modernity. Cambridge, UK: Cambridge University Press.

Harkness, Allan. 2012. Learning Approaches in Theological Education Institutions: Faculty and Student Expectations in a South Asian Seminary. The Journal of Adult Theological Education. 9, no. 2: 139- 157.

Ixer, Graham. 1999. There's no such thing as reflection. British Journal of Social Work. 29, no. 4: 513-527.

Ixer, Graham. 2010. There's no such thing as reflection: Ten years on. The Journal of Practice Teaching in Health and Social Work. 10, no. 1: 75-93.

Jaques, David and Gilly Salaman. 2006. Learning in Groups. London, UK: Routledge.

Johns, Hazel. 2012. $2^{\text {nd }}$ Edition. Personal Development in Counsellor Training. London, UK: Sage Publications.

Kelly, Ewan. 2012. Personhood and Presence: Self as a resource for spiritual and pastoral care. London, UK: Bloomsbury.

Kelly, Ewan. 2013. Translating Theological Reflective Practice into Values Based Reflection: A Report from Scotland. Reflective Practice: Formation and Supervision in Ministry. 33: 245-256.

Kinast, Robert, L. 1996. Let Ministry Teach: A guide to theological reflection. Collegeville, MN, USA: Liturgical Press.

Ladd, Nick. 2014. Theological Education at the Crossroads. Dialog: A Journal of Theology. 53, no. 4: 356-364.

Lee, Carl and Sarah Horsman. 2002. Affirmation and Accountability. Exeter, UK: The Society of Martha and Mary.

Lennie, Clare. 2000. The role of Personal Development Groups in counsellor training. Unpublished MA dissertation, Manchester University, UK.

Lennie, Clare. 2007. The role of Personal Development Groups in counsellor training: understanding factors contributing to self-awareness in the Personal Development Group. British Journal of Guidance and Counselling. 35, no. 1: 115-129.

Lyall, David. 2009. 'Supervision as Ministry'. Practical Theology. 2, no. 3: 317-325.

McBride, Jennifer, M. 2014. Christ existing as concrete community today. Theology Today. 7, no. 1: 92-105.

McLeod, John and Julia McLeod. 2014. Personal and Professional Development for Counsellors, Psychotherapists and Mental Health Practitioners. Buckingham, UK: Open University Press. 
Mearns, Dave. 1997. Person-Centred Counselling Training. London, UK: Sage Publications.

Moltmann, Juergen. 1973. Theology and Joy. London, UK: SCM Press.

Moon, Jennifer. 2004. A handbook of Reflective and Experiential Learning: Theory and Practice. London, UK: Routledge.

Nash, Sally. 2011. Regenerative Practice. Reflective Practice. 12, no. 3: 427-238.

Nash, Paul and Sally Nash. 2009. Tools for Reflective Ministry. London, UK: SPCK.

Preston-Shoot, Michael. 2007. $2^{\text {nd }}$ Edition. Effective Group Work. London, UK: MacMillan.

Reiss, Robert. 2013. The Testing of Vocation: 100 years of ministry selection in the Church of England. London, UK: Church House Publishing.

Rhymes, David. 1993. Time past to time future. London, UK: Darton, Longman and Todd.

Robson, Maggie and Jenna Robson. 2008. Explorations of participants' experiences of a Personal Development Group held as part of a counselling psychology training group: Is it safe here?. Counselling Psychology Quarterly. 21, no. 4: 371-382.

Rose, Chris. 2008. The Personal Development Group: The students' guide. London, UK: Karnac Books.

Rose, Chris. 2012. Self-Awareness and Personal Development: Resources for psychotherapists and counsellors. Basingstoke, UK: Palgrave Macmillan.

Schön, Donald. 1984. The Reflective Practitioner: How professionals think in action. New York, USA: Basic Books.

Sims, Neil. 2011. Theologically Reflective Practice: A Key Tool for Contemporary Ministry. Reflective Practice: Formation and Supervision in Ministry. 31: 166-176.

Taylor, John. 1972. The Go-Between God: The Holy Spirit and Christian Mission. London, UK: SCM Press.

The Archbishops' Council of the Church of England. 2003. Formation for Ministry within a Learning Church: The structure and funding of ordination training. A summary of the report [GS Misc 710]. London, UK: Church House Publishing.

Thompson, Sue and Neil Thompson. 2008. The Critically Reflective Practitioner. Basingstoke, UK: Palgrave Macmillan.

Travis, Mary. 2008. Supporting Clergy in Postmodern Ministry. Practical Theology Journal. 1, no. 1: 95-130.

Walton, Heather. 2014. Writing methods in Theological Reflection. London, UK: SCM Press.

Ward, Frances. 2005. Lifelong Learning: Theological Education and Supervision. London, UK: SCM Press.

Williams, Rowan. 2000. On Christian Theology. Oxford, UK: Blackwell Publishing.

Williams, D.I. and J.A. Irving. 1996. Personal growth: Rogerian paradoxes. British Journal of Guidance and Counselling. 24, no. 2: 165-172. 
Wolfe, D.M. and Kolb, D.A. 1980. Career Development, Personal Growth, and Experiential Learning. In Organisation Psychology: A book of readings, ed. Kolb, D.A., I. Rubin and J. Mclntyre. New Jersey, USA: Prentice Hall Publishing.

\section{Author}

Reverend Professor Peter Madsen Gubi, PhD, ThD, is Professor of Counselling and Spiritual Accompaniment at the University of Chester, UK, and Minister of Dukinfield Moravian Church, Cheshire, UK.

Email:p.gubi@chester.ac.uk 


\begin{tabular}{|l|l|l|l|l|}
\hline $\begin{array}{l}\text { Learning } \\
\text { Strategy }\end{array}$ & $\begin{array}{l}\text { Learning } \\
\text { Environment }\end{array}$ & $\begin{array}{l}\text { Primary } \\
\text { Mode }\end{array}$ & $\begin{array}{l}\text { Reflexive } \\
\text { Perspective }\end{array}$ & $\begin{array}{l}\text { Theological } \\
\text { Perspective }\end{array}$ \\
\hline $\begin{array}{l}\text { Concrete } \\
\text { Experience }\end{array}$ & $\begin{array}{l}\text { Emphasising } \\
\text { Personal } \\
\text { Experiences }\end{array}$ & $\begin{array}{l}\text { Feeling or } \\
\text { Getting } \\
\text { Involved }\end{array}$ & $\begin{array}{l}\text { Growing } \\
\text { awareness of } \\
\text { how I am } \\
\text { feeling }\end{array}$ & $\begin{array}{l}\text { Sensing the } \\
\text { Presence and } \\
\text { Action of God }\end{array}$ \\
\hline $\begin{array}{l}\text { Reflective } \\
\text { Observation }\end{array}$ & $\begin{array}{l}\text { Understanding } \\
\text { Concepts }\end{array}$ & Watching & $\begin{array}{l}\text { Awareness of } \\
\text { what this is } \\
\text { tapping into for } \\
\text { me }\end{array}$ & $\begin{array}{l}\text { Discerning } \\
\text { God's } \\
\text { Purpose }\end{array}$ \\
\hline $\begin{array}{l}\text { Abstract } \\
\text { Conceptualisation }\end{array}$ & $\begin{array}{l}\text { Preferred } \\
\text { Logical Thinking }\end{array}$ & Creating Ideas & $\begin{array}{l}\text { Making sense } \\
\text { of how I am } \\
\text { feeling and } \\
\text { responding }\end{array}$ & $\begin{array}{l}\text { Integrating } \\
\text { Into One's } \\
\text { Theology }\end{array}$ \\
\hline $\begin{array}{l}\text { Active } \\
\text { Experimentation }\end{array}$ & $\begin{array}{l}\text { Applying } \\
\text { Knowledge and } \\
\text { Skills }\end{array}$ & $\begin{array}{l}\text { Making } \\
\text { Decisions and } \\
\text { Doing }\end{array}$ & $\begin{array}{l}\text { Trying out a } \\
\text { different way of } \\
\text { being }\end{array}$ & $\begin{array}{l}\text { Deciding to } \\
\text { Co-Operate } \\
\text { with God }\end{array}$ \\
\hline $\begin{array}{l}\text { Figure 1. Adding reflexivity to Sims (2011) Further Definition to the Four Stages of Adult } \\
\text { Learning (Gubi, 2016a) }\end{array}$ & \multicolumn{3}{|l}{} \\
\hline
\end{tabular}

Figure 2. Foci for reflexivity

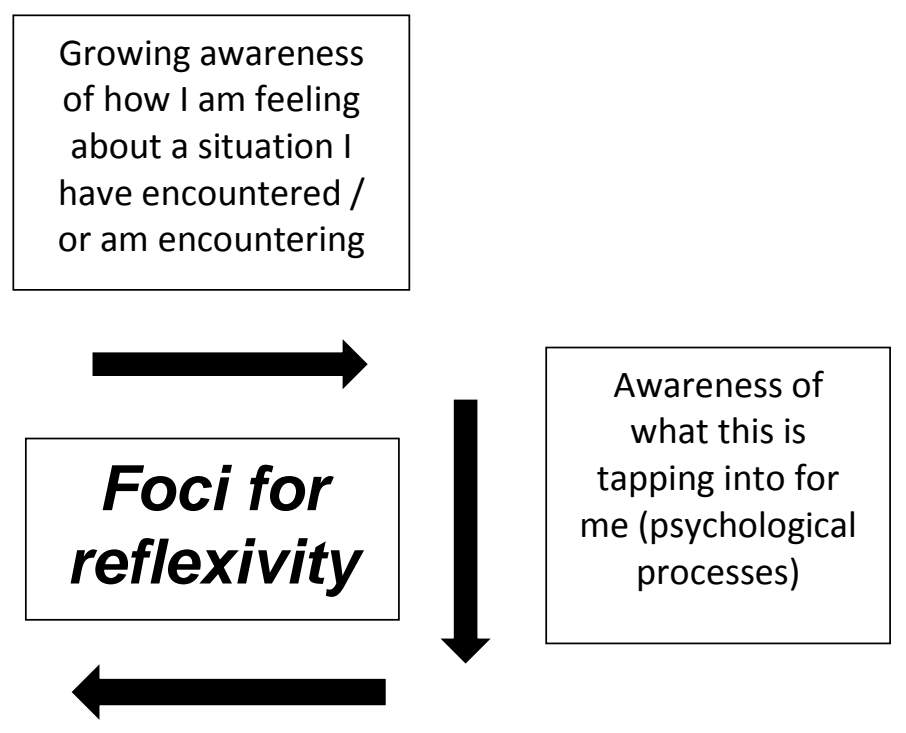

Deciding to cooperate with God.

Trying out a different way of being and thinking

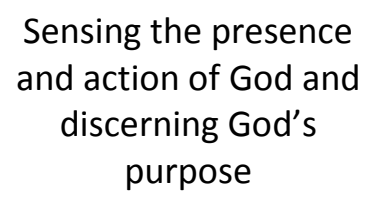

Sensing the presence and action of God and discerning God's purpose

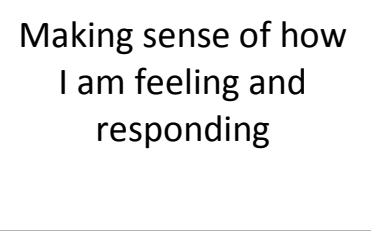

Figure 2. Foci for reflexivity in Reflexive Practice Groups 